TITLE:

\title{
MARINE INSECTS OF THE TOKARA ISLANDS -I. MARINE CRANEFLIES (DIPTERA, TIPULIDAE)-
}

$\operatorname{AUTHOR}(S)$ :

Nobuchi, Akira

\section{CITATION:}

Nobuchi, Akira. MARINE INSECTS OF THE TOKARA ISLANDS -I. MARINE CRANEFLIES

(DIPTERA, TIPULIDAE)-. PUBLICATIONS OF THE SETO MARINE BIOLOGICAL LABORATORY 1955, 4(2-3): 359-362

ISSUE DATE:

1955-05-30

URL:

http://hdl.handle.net/2433/174515

RIGHT: 


\title{
MARINE INSECTS OF THE TOKARA ISLANDS \\ I. MARINE CRANEFLIES (DIPTERA, TIPULIDAE) ${ }^{12}$ )
}

\author{
AKIRA NOBUCHI \\ Entomological Laboratory, Saikyo University
}

With 3 Text-figures

The present study was undertaken under the direction of Prof. Dr. Masaaki Torunaga on the materials collected by Messrs. Syôiti Miyamoto, Takehiko Nakane and Shun-ichi UÉNo at the coral reef and rocky shore of the islands.

There have hitherto been known 18 species of marine Tipulids, including 4 Japanese species of Idioglochina and Dicranomyia respectively. The marine craneflies from the Tokara Islands are identified with Limonia (Idioglochina) tokunagai Alexander and Limonia (Dicranomyia) tokara n. sp. Thus, at present I intend to report a new marine cranefly with its description.

I express my cordial thanks to Prof. Dr. Masaaki Tokunaga and Mr. Mitsuhiro SASAKAwA of Saikyo University, for their useful suggestions on this investigation. I am also indebted to Messrs. Syôiti Miyamoto, Takehiko Nakane and Shun-ichi UÉNO, members of the Tokara Expedition, for their kindness in collecting the materials. Further, I wish to express my thanks to Miss Etsuko KōMYō for her kind help given on this study.

\section{Limonia (Idioglochina) tokunagai ALEXANDER}

1932. Philipp. Jour. Sci., 49: 113-115.

A male specimen; Nakanoshima Island, Tokara Islands; June 10, 1953; Shun-ichi UÉno leg. A male and a female; June 10, 1953; Syôiti Miyamoto leg.

Distribution:-Kii Peninsula, Okinoshima, Danzyo Islands (Kyushu) and Nakanoshima Island.

1) Scientific Survey of the Tokara Islands, Report No. 15.

2) Contributions from the Entomological Laboratory, Saikyo University, Kyoto, No. 23.

Publ. Seto Mar. Biol. Lab., IV (2-3), 1955. (Article 29) 


\section{Limonia (Dicranomyia) tokara sp. nov.}

Male:-Body length about $4.5 \mathrm{~mm}$; general coloration of body dirty yellow; mouth-parts and antennae yellowish brown; eyes entirely black; mesopraescutum with longitudinal stripe broadly brown on central part; thoracic notum with lateral brownish stripes extending from middle of mesopraescutum to caudal margin of mesoscutum; pleural side with a dark brown distinct stripe extending from cervical sclerites, through beneath wing and halter, to seventh abdominal segment; abdominal tergites brown and sternites dirty yellow, but in some paratopotypical specimens tergites and sternites brown and with a pale band on caudal margin of each segment.

Head thinly covered with setae; eyes bare; antennae 14-segmented; flagellar segment almost oval, with about five setae; ultimate segment (Fig. 2) slightly smaller than penultimate $(1: 1.2)$. Maxillary palpi relatively short. Wings (Fig. 1) about $5.5 \mathrm{~mm}$ in length, pale brown and hyaline, stigmal area not clouded; veins brown. Venation: $\mathrm{Sc}_{1}$ ending before origin of $\mathrm{Rs}, \mathrm{Sc}_{2}$ lacking, $\mathrm{m}-\mathrm{cu}$ before or at fork of $\mathrm{M}$, median cell opened cross vein being atrophied, $\mathrm{Cu}_{2}$ closely extending beneath $\mathrm{Cu}_{1}$. Halteres yellowish white. Legs brown; coxae, trochanters and basal half of femora paler, proportional lengths of segments of legs, excepting two proximal segments, as follows: $5.3: 6.8: 4.45: 1.5: 0.6: 0.3: 0.3$ in fore, $6.2: 6.6: 3.3: 1.45: 0.7: 0.3: 0.3$ in middle, and $7.0: 7.6: 3.6: 1.5: 0.75: 0.35: 0.5$ in hind leg $(1.7$ units $=1 \mathrm{~mm})$; third and fourth tarsal segments of all legs with a row of apical setae on apical half of ventral side. Claws rather strongly bent at middle and with a long basal tooth. Abdominal octatergum narrow, not subdivided; novatergum with marginal setae on lateral and caudal sides, inverted trapezoid, its caudal margin being shorter than cephalic margin; its caudal margin slightly concave and with a small blunt projection at center. Hypopygium (Fig. 3) with chitinized parts brown; coxite elongate, with setae relatively sparse; ventral lobe of coxite rather broad; style bare, strongly curved at distal part; ventral style with rostral projection which is setigerous apically and provided with a black stout needle-like process; aedeagus comparatively slender.

Female :-Body about $5.5 \mathrm{~mm}$. long, similar in coloration to male, excepting dark brown abdomen. Wings about $5.3 \mathrm{~mm}$ long. Proportional lengths of segments of legs as follows : $4.2: 5.3: 2.95: 0.95: 0.43: 0.3: 0.35$ in fore, $5.6: 5.45: 2.35: 1.05: 0.5:$ $0.35: 0.35$ in middle, $6.2: 6.15: 2.9: 1.15: 0.5: 0.3: 0.3$ in hind leg $(1.7$ units $=1 \mathrm{~mm})$; apical three tarsal segments of all legs with a row of special setae on ventral side; claws comparatively small, with three basal teeth. Hypopygium cerci longer than twice of basal width $(2.2: 1)$, octavalvae short, but longer than their basal width $(1.5: 1)$.

Habitat:-Tidal zone of the Pacific coast, Ryukyu, Japan.

Holotype:-Male ; Nakanoshima Island, Tokara Islands; June 10, 1953; Takehiko NAKANE leg. 


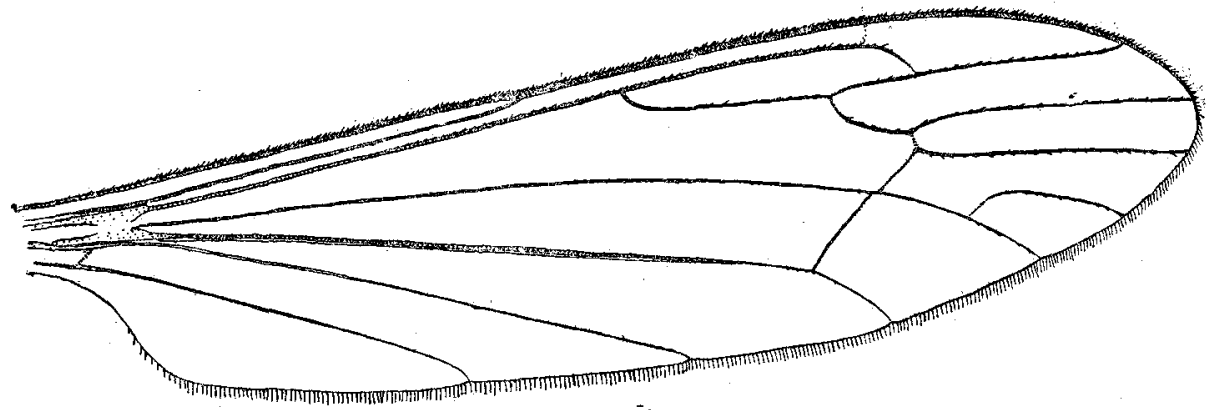

1
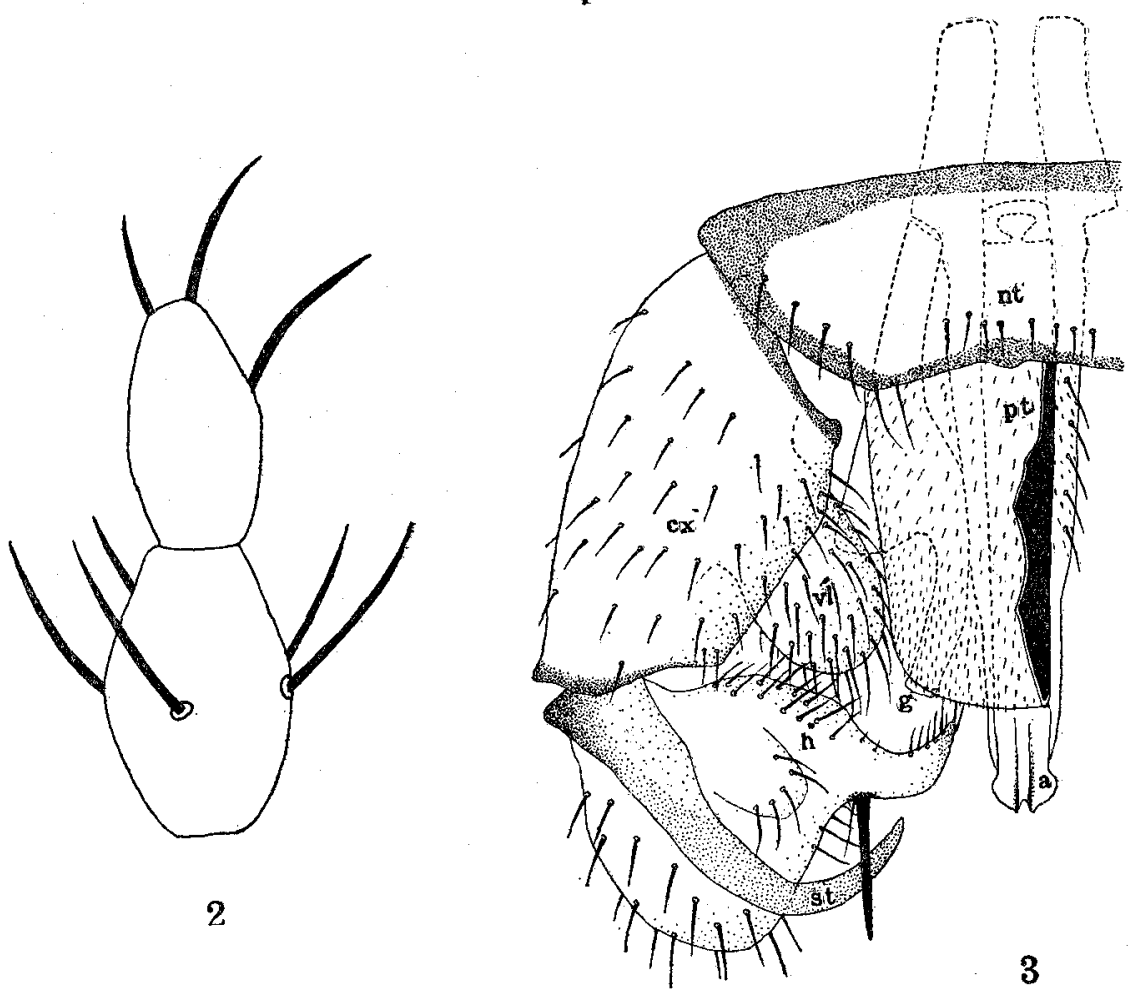

Limonia (Dicranomyia) tokara n. sp.

Fig. 1. Male wing.

Fig. 2. Ultimate two segments of male antenna.

Fig. 3. Male hypopygium, dorsal aspect. 
Allotopotype:-Female; June 10, 1953; Takehiko NAKane leg.

Paratopotypes:-72 males and 7 females; June 10, 1953; Takehiko Nakane leg. 4 males; June 10, 1953; Shun-ichi UÉNo leg, together with Limonia (Idioglochina) tokunagai ALEXANDER.

Type specimens:-Alcoholic; deposited in the Entomological Laboratory of Saikyo University.

This new marine cranefly is related to Limonia (Dicranomyia) halobia ToKunAGA (Amakusa Islands, Japan), but differs from that in the following characters: dark brown stripe of thorax and abdomen, relative size of two distal segments of antenna, specific shape of abdominal tergite of male hypopygium and a strong needle-like process of ventral style of male which is not a seta nor bristle.

\section{LITERATURE}

Alexander, C. P. 1932. New or little-known Tipulidae from Eastern Asia (Diptera), X. Philip. Jour. Sci., $49: 112-115$. 1933. Ditto, XIII. Philipp. Jour. Sci., 51: 391-395.

TokunaGa, M. 1930. The morphological and biological studies on a new marine cranefly, Limonia (Dicranomyia) monostromia, from Japan. Mem. Coll. Agric. Kyoto Imp. Univ., 10: 1-93.

1936. Three marine crane-flies from Japan. Annot. Zool. Japon., 15: 460-468.

1937. Marine Diptera from the Danjo Islands. Trans. Biogeogr. Soc. Japan, $2: 34-38$.

1938. A new marine crane-fly from Japan. Annot. Zool. Japon., 17: 165-169.

1940. Revision on marine craneflies (Tipulidae) with descriptions. Kontyu, 14:133-

148 